\title{
Topographical Reconstruction of Ancient Palermo: A Note on its Buildings for Public Spectacles and their Relation with the Roman-Period Civic Planning
}

\author{
Paolo Storchi \\ Sapienza Università di Roma \\ email: paolostorchi1Avirgilio.it
}

\begin{abstract}
Topographical studies in the last decades have greatly improved our knowledge of Roman Panormus (modern day Palermo) but many aspects of its urban planning still remain obscure. It is very hard work to clearly understand a city that has been continuously inhabited from at least the Iron Age to the present. This long standing existence implies countless transformations of its urban aspect. In particular the Arab domination, in the Middle Ages, erased even the memory of the ancient place names, so the toponomastic source that is often a fundamental tool for the ancient topographer is almost useless. Using the typical sources of ancient topography and landscape archaeology and its multidisciplinary approach can be exceedingly useful in understanding the ancient aspect of a living city. We found an important lack of information about ancient Palermo: the location of buildings designed for public spectacles. The epigraphic sources prove that in Palermo there was a theatre and an amphitheatre; from a Late-Antique source we can assume that there was also a circus. This paper's aim is to suggest concrete hypotheses to identify the locations of all three of these buildings, discuss their position and their relation to the civic plan of Panormus. These results are important in understanding this city in a more complete way but also for the protection of its archaeological heritage: these three areas lie outside the ancient walls of Palermo and have hitherto been considered "low-risk areas" for archaeology. manifestations
\end{abstract}

Keywords: Ancient topography, Roman urbanism, Amphitheatre, Aerial photography, Ancient Sicily

\section{Text}

The urban organisation of ancient Palermo remains largely unknown; it is very hard work to clearly understand the steps that led to its present appearance and transformation from Panormus into Palermo. This is a city that has been inhabited without interruption from the Iron Age to the present. Such a long and continuous settlement history entails countless transformations of the urban aspect for any city, and Palermo is no exception. In Late Antiquity, with no governmental control, urban roads and squares gradually began to be occupied by houses and huts, sometimes leading to the complete disappearance of Punic and Roman city structures. In the Middle Ages, with the emergence of new strong powers, new squares were created around the new economic, religious and political poles of the city. These new poles acted like magnets, attracting new streets to them, thus destroying former homes, buildings and roads and changing the cityscape forever. Even as recently as the nineteenth and twentieth century, the city centre was criss-crossed by large roads built either for political reasons or to reduce traffic congestion (such as via Roma, constructed in 1906). Nor should we forget also the role of the continual sedimentary deposition by the two rivers, Papireto and Kemonia, which surrounded the town on the north and south sides. Today they are only little subterranean canals, but until the Middle Ages they were proper rivers and were able, little by little, to significantly push back the coast line. Another problem is that Arab domination erased every memory of names of the ancient place, so that the extant toponym analysis, which is often a fundamental tool for the ancient topographer, is 


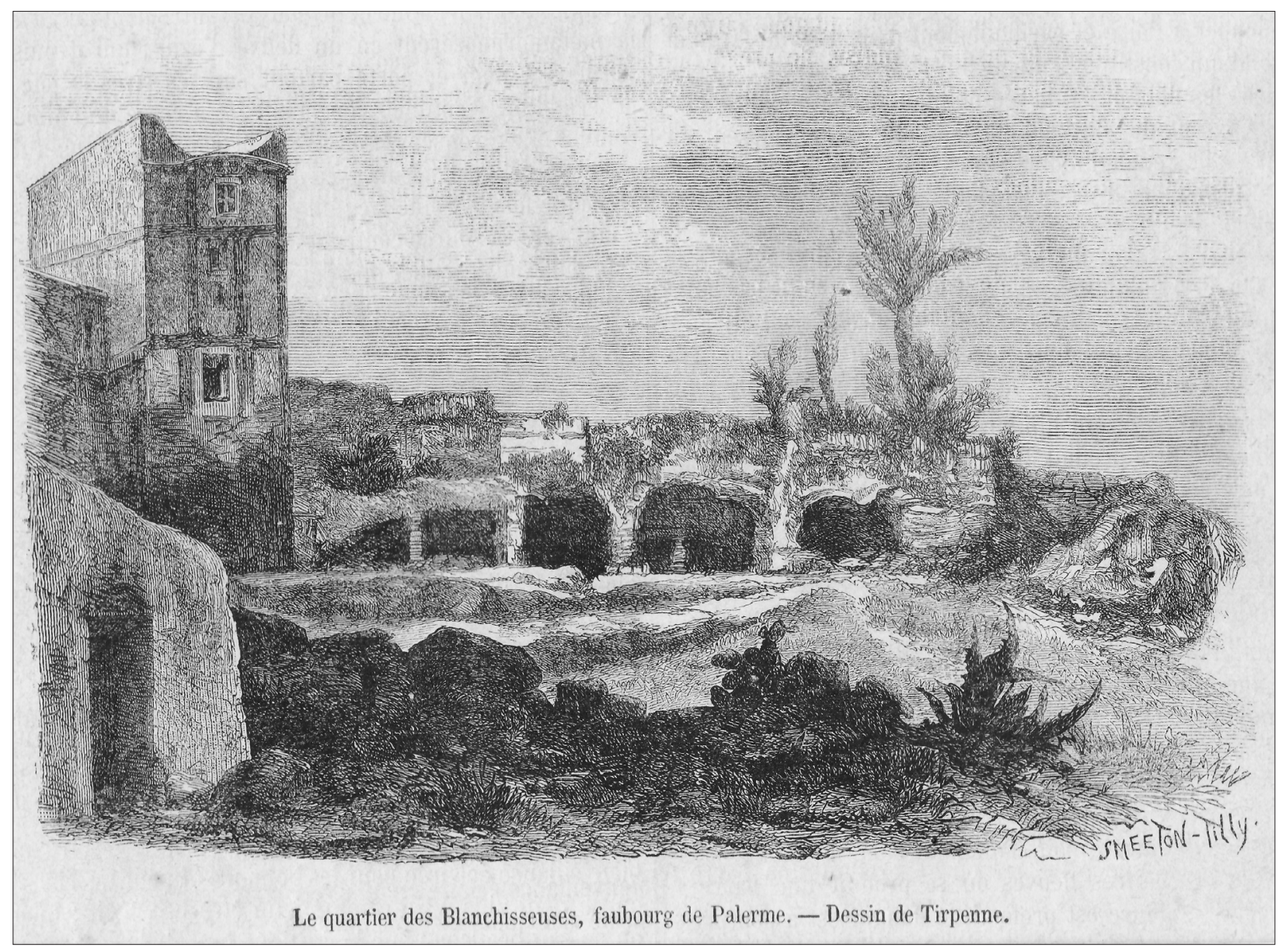

Fig. 1. An engraving published by the French Journal Le Magasin Pittoresque in 1874. It illustrates a building in Palermo located in the unknown "laundry-women district". It should be noted its extraordinary similarity to an ancient theatre.

almost useless. A survey of ancient place names in Palermo was conduct by 0 . Belvedere (Belvedere, 1987) who found that, in the whole city, only two toponyms earlier than the period of Arab control survived: "Porta Sant'Agata”, an ancient city-gate that took its name from an old church nearby, and "San Calogero in thermis". This name refers not to Roman baths, as the term "thermis" might suggests, but to a natural thermal spring so it gives little value for the reconstruction of the ancient city.

Nevertheless, in the last decades, topographical studies (Belvedere, 1987; 1998), archaeological excavations (Di Stefano \& Mannino, 1984; Spatafora \& Montali, 2006) and geological prospections (Todaro, 1995) have greatly improved our knowledge of Panormus. In particular Belvedere studied the current urban plan using a metrological approach. His work revealed that, despite all the changes to the city, the distance between most of the present-day roads and alleys, in the area between the two rivers mentioned above, perfectly corresponds to a Punic measurement: a multiple of the great cubitus of $52.18 \mathrm{~cm}$. The width of the ancient blocks seems to be precisely 100 cubits: an astonishing survival of the ancient Punic street system in the present-day urban plan. This hypothesis has been recently confirmed by the discovery of ancient road sections under a few contemporary streets (Spatafora \& Montali, 2006). The most important consequence of this is the certainty that the city presents a strong persistence of its Punic and Roman past: if we are able 
to identify, and then exclude, the medieval and modern alterations, we can actually try to discern the ancient Panormus.

As archaeological excavations reveal, the Punic system was also maintained under the Romans and, to a large extent, even up to the present, at least in its general form. Another proof of Palermo's propensity to conserve its ancient urban shape is the fact that the internal division between the first Punic village (Palaeopolis) and the later expansion (Neapolis), probably dating to the fifth century BC, was marked by a wall on the west side of the city and this division was preserved until the fourteenth century AD. By contrast, the consideration that on the north, south and east sides the Punic walls were restored and used by the Romans and then by the Byzantines is less significant. The reason for this continuity is actually only due to a basic principle of poliorcetics: the walls were built along the steep river banks, thereby enhancing the defensive value of the river itself. As already noted, geological studies also offer important data: deep corings were especially valuable to finally understand the exact extension of Palermo's harbour, whose width gave the city its name, and to identify the docking areas (Todaro, 1995).

Although the general shape of the city is now known, and archaeology (Di Stefano \& Mannino, 1984) has revealed some wealthy Roman domus, we still know nothing about the public areas and buildings of Panormus. We know absolutely nothing about its temples, baths, horrea; even the forum is only speculatively identified in the area of "Palazzo Reale". Nevertheless Panormus was one of the most important towns in Sicily in the Imperial period. It was granted the status of colony under the reign of Augustus or that of Septimius Severus (Vera, 1996), so it is likely that the city was equipped with several grand buildings.

Important, therefore, is an iscription from the second century $A D$, engraved on a white marble slab that was re-used in early modern period in the San Cataldo church lat the city's eastern boundaryl, which tells us that there were at least two buildings for public spectacles in the city.
Given its significance, it is worth quoting here the whole text, with an English translation ICIL X 7295):

[curatori kalendarii? --- ]iani quod mera fide admi-

[nistravit eodemque tempore] curlatori) portensis kallendaril quod singulari

[diligentia tractavit, ---- I]audabili munerario qui indulgentia

[sacra cum munus --- ex] hibuit illut meruit optando quod voluit

[et universis civibus --- ed]itionem gratissimam reddidit quod die-

[bus--- populum per multa]s horas theatri voluptas tenuit et hilaris

[totus in harenam --- inde a] meridie transiit in qua miratus honestissimum

[apparatum inscriptum--- omni] genere herbarium et numerosas orientales

[feras versatusque --- inde a] meridie in utriusque caveis var(i)s missionibus

[delectatus est, idemque ex indulg]entia sacra specialiter meruit at cultum

[epulum instructumque --- a]mplissimo apparatu cives suos universos

[ut vocaret cui cum populus propter] volup-

tates honeste exhibitas ad augendam

[optimi viri honoreficentiam freq]uentissimis vocibus bigas centuriatim

[postulasset, motus --- verec]undia quod esset duabus bigiis et equestrib(us)

[statuis tribus (?) contentus ---]

Translation: [...] for Aurelianus because, deeply devoted, in the same time, he managed [...] and he administered the harbour-register with peculiar assiduousness [...] he organised public spectacles with the specific permission of the Emperor [...] he showed what deserved and wanted and he offered to all the citizenry an absolutely remarkable exhibition of games that for days [...] entertained people for many hours in the theatre and with dancers, in the arena [...] then at midday, amazed at an extraordinary inscribed equipment [...] with 
all kind of herbivorous animals and many beasts taken from the Orient and he worked for [...] after midday he pleased the community, in both the buildings for public spectacles, with many hunts, and had himself a particular prestige and prepared the cult-banquet [...] with a great organisation for accommodating all the people living in his city, for the great time he gave them, the people asked many times, shouting, to give this good man, for his honour to increase, statues of him on a chariot: one statue in every district, moved [...] but out of modesty he was content with [...] two statues of him on a chariot and three on horseback.

Aurelianus, who was given the title of munerarius (for this title see Carlsen, 1994), held lavish spectacles in Palermo, and so we can be certain that the city had a theatre (theatri) and an amphitheatre (in the epigraph quoted above an harena, gladiator fights, venationes are mentioned and another important inscription from Palermo, C/L $X 7297$, mentions a secutor and a coarmius, two gladiators). Literary sources allow us to assume that Panormus probably also had a circus. The anonymous author of the Descriptio totius mundi, written in the reign of Justinian, describes chariot races held in Palermo. Although archaeologists have found no archaeological evidence of this structure yet, J. H. Humphrey, the writer of the most important work on circuses in the Roman Empire, thinks that 'Palermo remains a likely candidate for some kind of circus' (Humphrey, 1986: 575-76). In a recent paper (Storchi, 2013), I focused on this problem, proposing new identifications for all three of these buildings. I believe that these conclusions are still valid, but the situation can be analysed more completely and a new hypothesis suggested.

Before my study, only a few attempts had been made to locate these buildings. I. Tamburello (1971) wrote that we should look for the amphitheatre in the San Cataldo district because this is the area where the inscription of Aurelianus was found. I think that this idea is unconvincing. As mentioned above, the inscription was reused in the early modern period and we do not know where it was originally located before it was used in the church wall. Furthermore even if it had been found in that same area, we do not know its original context of display. The text mentions statues and honorary monuments donated by the city to Aurelianus as a gift for the spectacles he organised. This inscription could thus have been a part of one of these monuments or of the pedestal of one of these statues, not all of which were necessarily located near the amphitheatre or theatre. On the other hand, one tradition placed an ancient building for public spectacles, perhaps the theatre, at the "Sala Verde", a section of the Royal Palace of Palermo lalso known as "Palace of the Normans"). We cannot study this building since it was dismantled in order to build Sant'Antonio's convent in 1447, then the city walls in 1549, and finally the whole area was levelled in 1554 (Fazello, 1628). Analysing all the data available about the "Sala Verde" the historian V. Di Giovanni (1890) considered the possibility that this had originally been a theatre unlikely. In fact the shape of the building was not semi-circular but squared, thus ruling out a theatre. It also seemed to have a roof and theatres were typically open-topped. Given this and its location, in one of the most likely positions for the forum of Panormus, if it really was an ancient Punic or Roman structure, we can only imagine that it was something connected with the political or judicial life of Panormus rather than a theatre.

Di Giovanni hypothesised instead that the theatre was in via Montevergini. In fact, in a fifteenth century purchase agreement a building sold on this road was termed theatrum. This street is the successor of an ancient Punic and Roman road in Panormus but, until now, there have been no further clues to identify the theatre in this area: there are no anomalies in the city street system and archaeological excavations have only revealed the presence of Roman private residences (Garofano, 1997-1998).

Investigating further, I found an unusual illustration of Palermo (fig. 1) in the French magazine Le Magasin Pittoresque, published in 1874. It was engraved by the famous English engraver Burn Smeeton and the Frenchman Auguste Tilly, who formed a partnership in Paris in the last 


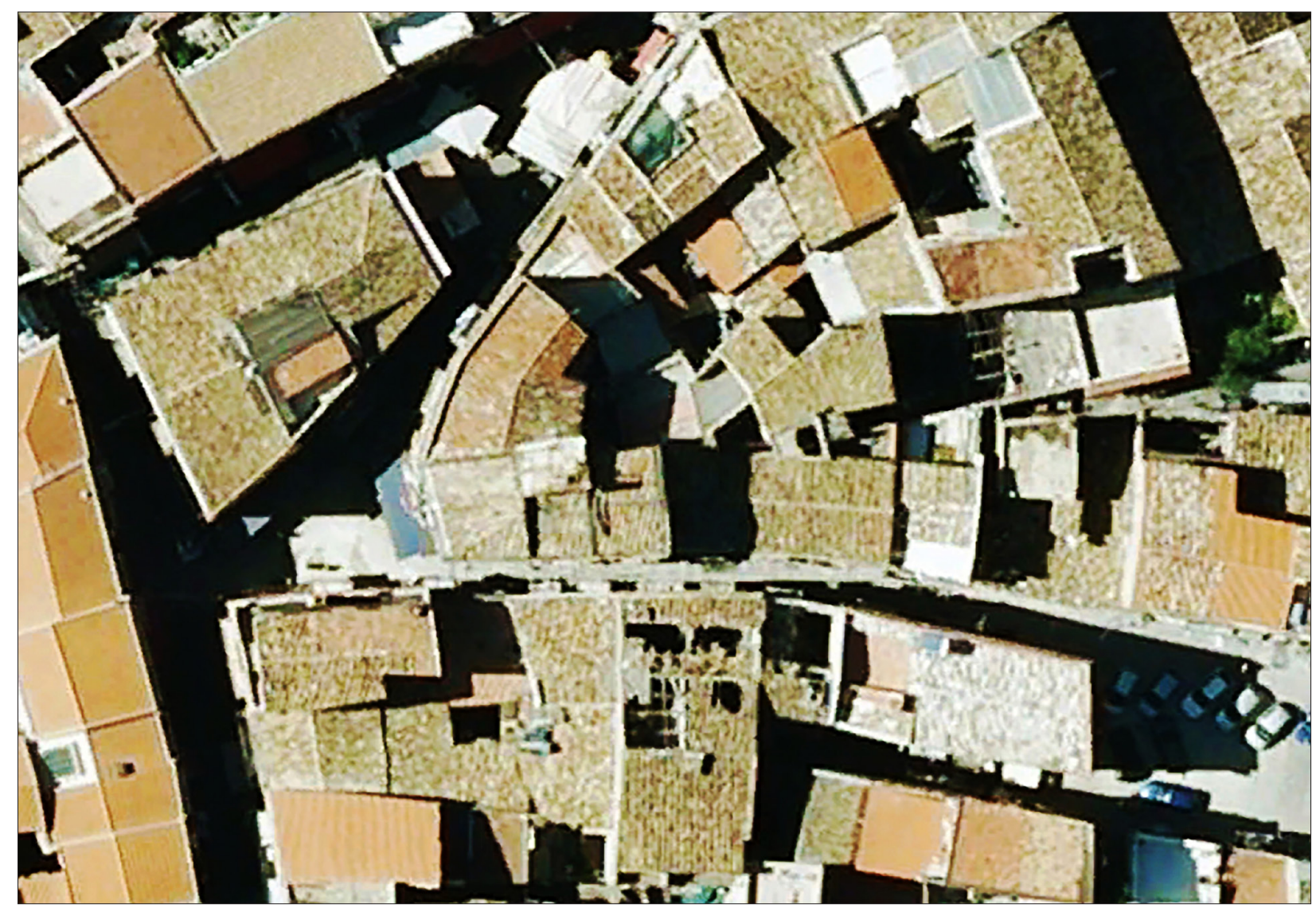

Fig. 2. Satellite Image (Google Earth 2007) of the area between Piazza and Piazzetta San Gregorio. A peculiar semi-circled shape area is visible and could correspond to the building depicted in the engraving.

decades of nineteenth century. It depicts a building characterised by its extraordinary similarity to an ancient theatre. The image caption informs us that this building was in le quartier des Blanchisseuses, fauburg de Palerme, so we know that it was in the "laundry-women district" and that this quarter was not properly in the city centre. It is very difficult to exactly locate this picture in the present-day city because in Palermo there is no "Laundry-women" district: it must be an unofficial name that people used for this area. In 2013 I hypothesised that this building could be near via Panneria, whose name could be translated as "the road of clothes-production" or "where clothes are washed". The two toponyms seemed semantically connected and, furthermore, if one extended via Montevergini, where the theatrum was, towards the north, one would reach precisely via Panneria.

In this paper I aim to propose a new hypothesis. This illustration could refer to the area of Piazza and Piazzetta San Gregorio. In fact the satellite image of this district seems to indicate a semi-circle shaped area (fig. 2) and it is possible to notice a gap exactly where the engraving shows a crumbling structure made of wood and other perishable materials. Moreover, it is out of the city-centre, as written in the image caption, and the nineteenth-centrury cadastre (Mortillaro-Villarena, 1853) informs us that a road near Piazza San Gregorio was known as via del Saponaro, "the road of the soap maker/seller". This toponym could also be semantically connected with "laundry-women". This area is closely related to the ancient Via Valeria, an important Roman road corresponding currently to via di Porta Carini (Uggeri, 2004) and far from the Papireto wetlands, in an area charac- 


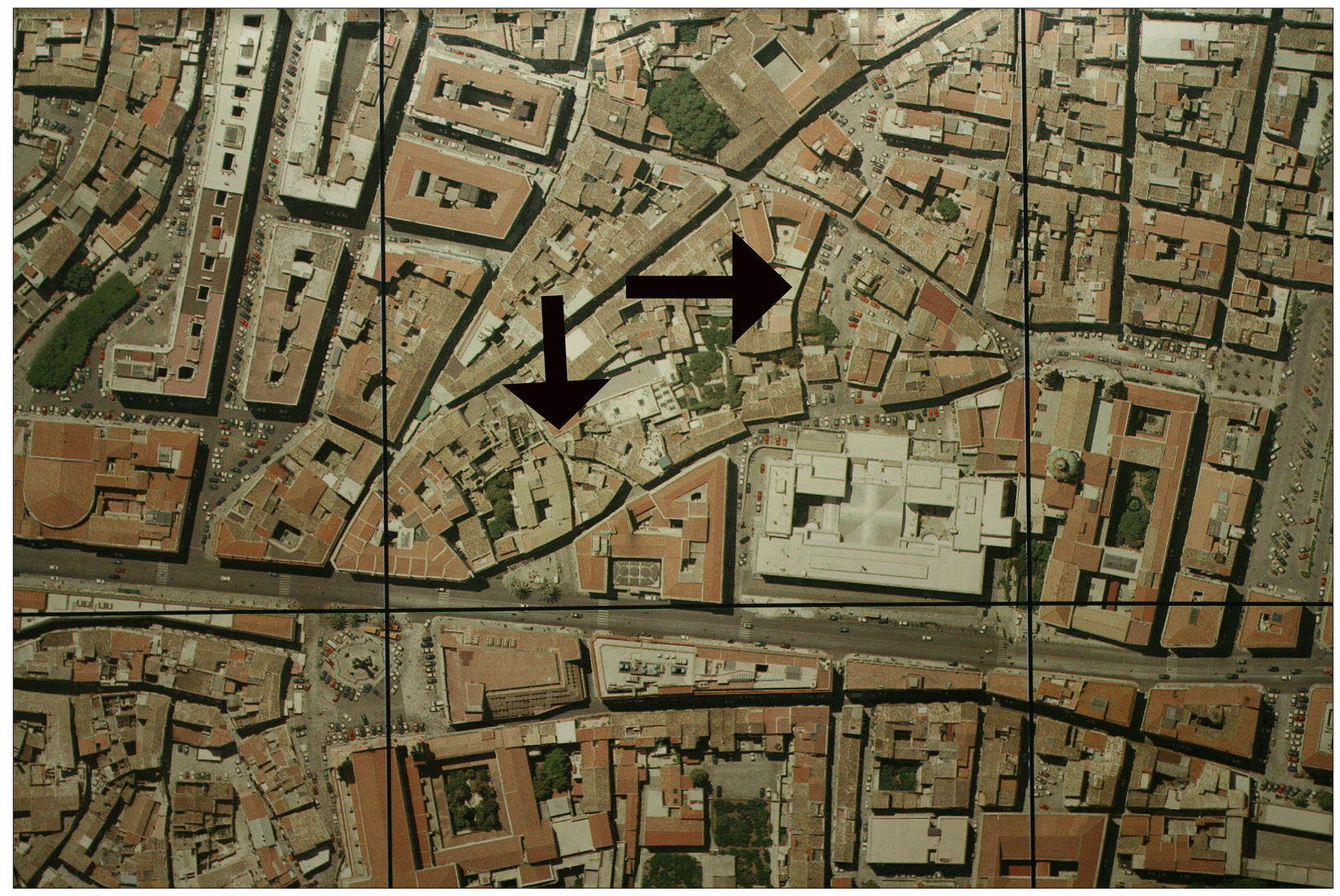

Fig. 3. Aerial photo (Regione Siciliana, CRICD) of the area of Piazza San Domenico. On the left the possible amphitheatre, on the right the area where the circus could have been.

terised by strong and solid ground: a perfect position for these buildings. It should be noticed that the length of the scaena seems to be only about $30 \mathrm{~m}$, and so, if it was indeed a building for public spectacles, it cannot be excluded that this was an odeon rather than a theatre. The quest for the ancient theatre of Palermo is still an open question but some interesting clues have been found which hopefully will lead to a precise identification in the near future.

Observing aerial and satellite photos of Palermo, I found another peculiar pattern created by the present-day streets and building roofs around the area of Piazza San Domenico (fig. 3) which give a visibly curved shape to the district. Upon examining the old documentation about the area, I found that in one of these buildings, a few metres to the west of the round mark, known as "Protomedico Pizzuto's house" and at least until 1938, there was a large marble column with a Corinthian capital on top. Nino Basile (1938), who first noticed this column, described it as "mysterious" because nobody could understand from which ancient Roman building nearby it could have been taken. In the light of the curved shape of the district and of what has been said before about the theatre, it seems worthy to hypothesise that this column could have been taken from the amphitheatre, or even that it could still have been standing in its original position, probably on the external facade of Panormus's most majestic building for public spectacles. It is impossible to give a measurement of the axes of the building; the trace is too evanescent and does not allow us to precisely understand the orientation of the building nor even whether the round trace delimits the entire amphitheatre or only the arena where fights took place. The destruction caused in order to create Piazza San Domenico (in 1458 and then again in 1724) has compromised the coherence and legibility of the 


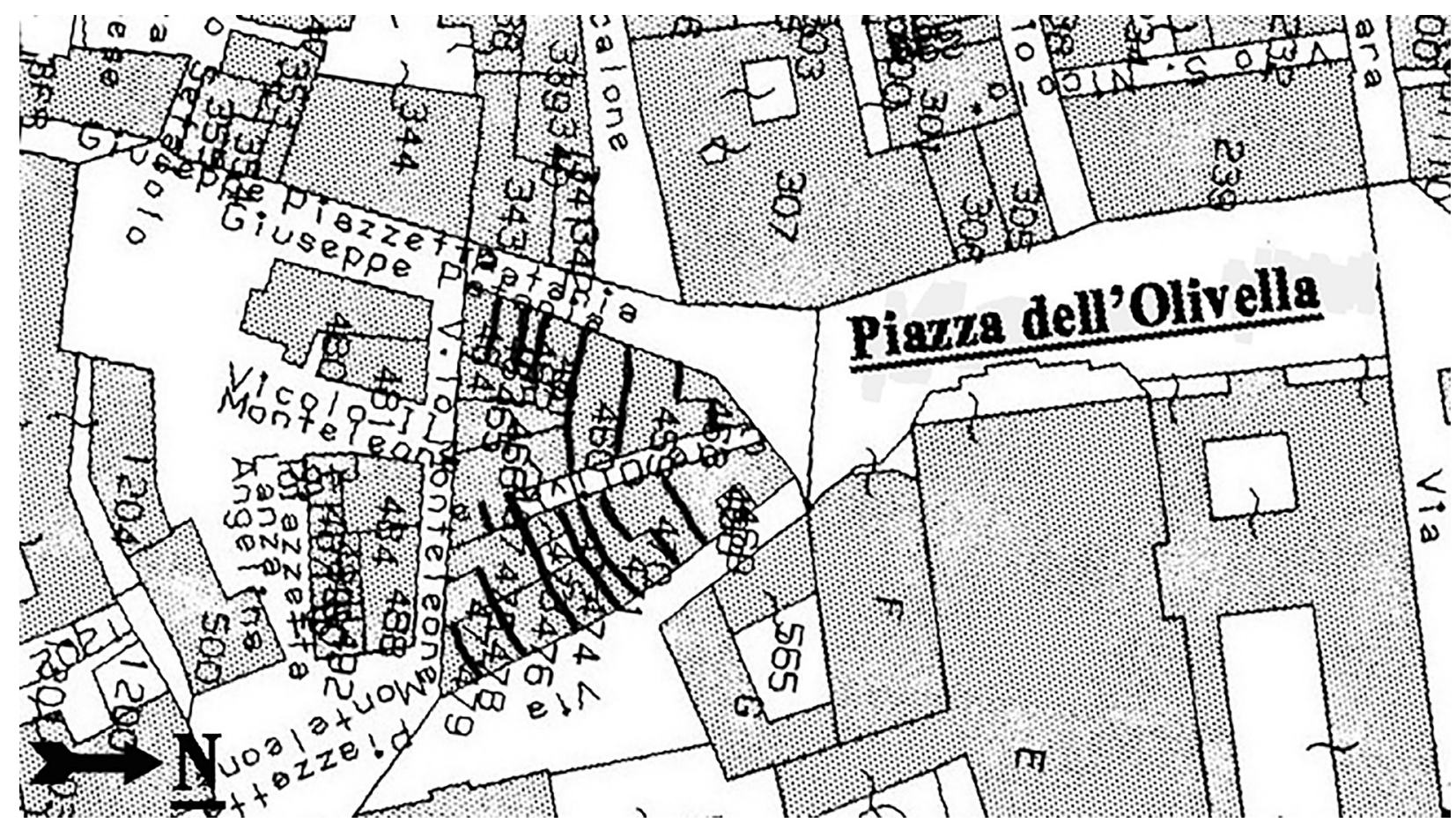

Fig. 4. Extract of the present-day cadastre of the area of Piazza dell'Olivella in Palermo. Note the anomalies in property divisions.

structure. Purely for illustrative purposes, it is possible to estimate that the length of the axis on via Roma is about $85 \mathrm{~m}$.

An important confirmation of the hypothesis that the anomalous shape in this part of the city corresponds to an amphitheatre comes from the analysis of the ancient (Mortillaro-Villarena, 1853) and current cadastre. The internal divisions of the buildings in this area show what seem to be the typical wedge-shaped chambers of a building for public spectacles. It also should be noted that the traditional emblem of this district is Hercules strangling the Nemean lion, we could say, a Hercules venator.

Near the supposed amphitheatre I found other anomalies in the current cadastre (fig. 4) that seem to indicate wedge-shaped chambers and long semi-circular lines identifiable through various individual properties. I therefore started an urban survey that led to the discovery of a num- ber of reused building materials, such as column drums, entire marble columns and architectural elements (Storchi, 2013). These precious building materials were found in the area of Piazza dell'Olivella or Square of the Small Olive. This toponym could allude to the shape of this square, very long and narrow, similar to a circus track. Another interesting place name has been found in the area: “Ciccu di Palemmu" (Di Liberto, 1993). I think that this name could originate from the Latin circus of Palermo; so it seems likely that the circus could have been here.

In the present state of our knowledge about ancient Palermo, we can assume that the buildings for public spectacles lamphitheatre, circus, and theatre/odeon) were all outside the city walls, with the possible exception of the theatre, if it was indeed in via Montevergini (fig. 5). This is easily explained by the fact that when the Romans conquered Sicily they found a fully structured Panormus, as the persistence of the Punic urban system demonstrates, it would have been quite complicated to insert new large-scale buildings like these. This would have implied the requisition, destruction, and re-building of entire districts. Amphitheatres, theatres, and circuses were, in Roman time, a suite of buildings that were desirable addictions 


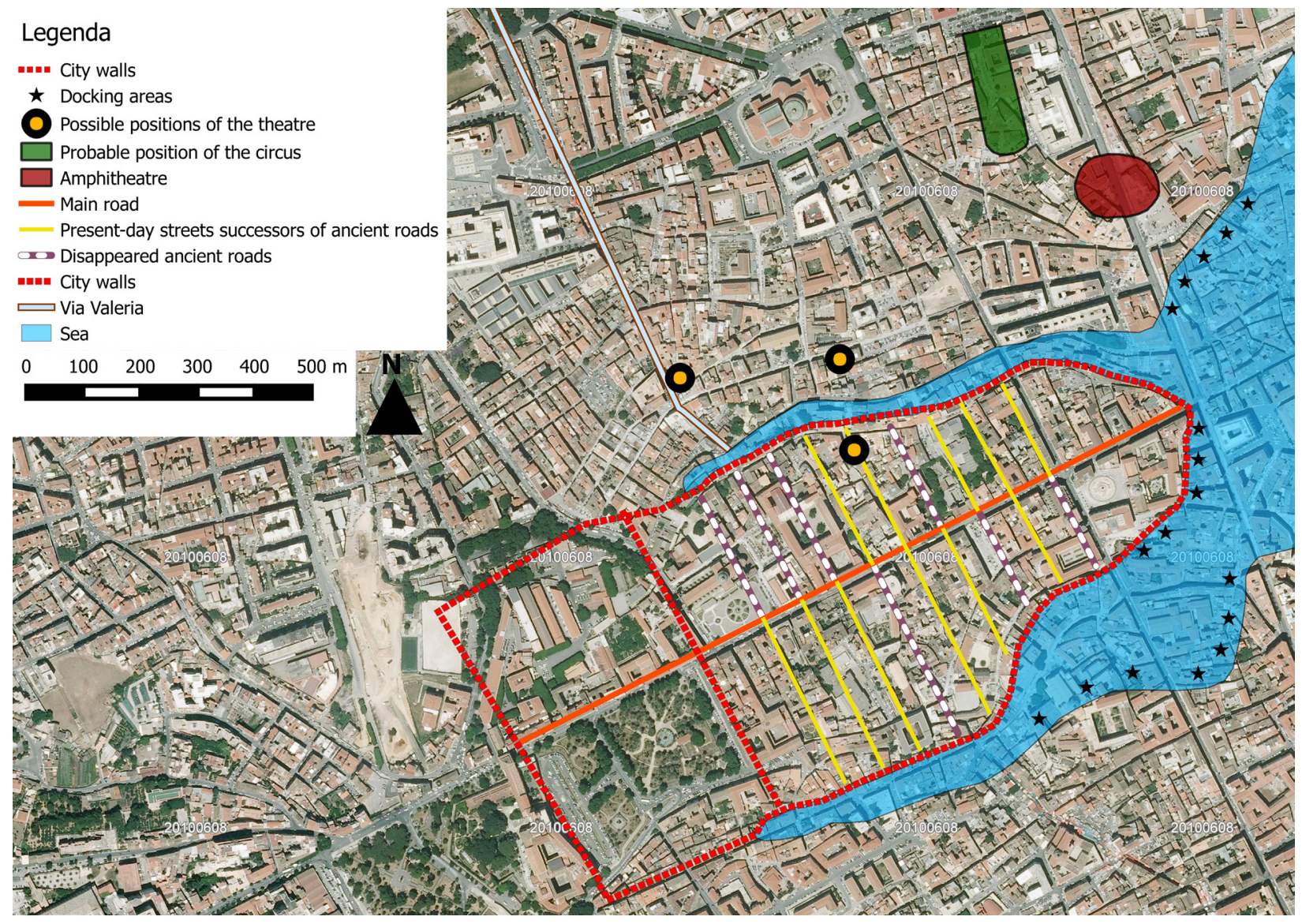

Fig. 5. Overview of Palermo with the indications of the Roman urban street-system and the localisation of spectacle buildings proposed lelaborated by author using Qgis, the background photo is taken from "Geoportale Nazionale" service: http://www.pcn.minambiente. it/GN/J.

to urban life (Wilmott, 2008) but in such a situation it was much easier to build them out of the city.

In conclusion, I would like to stress that the position of these buildings in the city plan seems not to be coincidental, corroborating the likelihood that their location is as I supposed. The theatre/ odeon is located near the Via Valeria, one of the most important extra-urban roads of ancient Sicily (Uggeri, 2004). This position would have given great visibility to the building land perhaps to the family or emperor who erected it) but the connection to a great road was fundamental for other reasons. It would have made it easier for the audience to access and leave the building during the days of the shows and, during the construction phase, it would have been much easier for building materials to reach the construction site. Exactly for the same reasons, the other two buildings seem to have been built in close proximity to one of the most important docking areas of the city-harbour.

The importance of these considerations rests not only on the attempt to fill a gap in our knowledge of the urban plan of Roman Palermo: it also has consequences for the protection of the city's archaeological heritage. These three areas are located outside the ancient Punic and Roman walls and have therefore been considered "low-risk areas" for archaeology.

Archaeological excavations are always crucial to understand how a living city was in the past but sometimes the data resulting only from them are not enough due to the fortuity of the archaeological records and to the luck of discoveries. Although this research is still ongoing and these 
identifications are hypotheticals, I believe that this work demonstrates once again the values of the contributions offered by the field of ancient topography and landscape archaeology. Only by drawing on multiple sources and interdisciplinary methods, is it really possible to understand an ancient city and to care appropriately for its heritage.

\section{References}

Mortillaro-Villarena V, 1837-1853: Catasto borbonico della città di Palermo, Archive of Regione Siciliana, CRICD.

Basile N, 1938: Palermo felicissima: divagazioni d'arte e di storia, vol 3, Cardella, S (ed.), Antiche strade e piazze di Palermo, Stamp. F. Sanzo \& C., Palermo.

Belvedere 0, 1987: Appunti sulla topografia antica di Panormo, Kokalos, 33, 289-304.

Belvedere 0, 1998: Studi di Topografia antica, in Palermo punica: 71-78. Sellerio, Palermo.

Carlsen J, 1994: Gli spettacoli gladiatorii negli spazi urbani dell'Africa romana. Le loro funzioni politiche, sociali e culturali, in Mastino A \& P Ruggeri, L'Africa romana, Atti del X Convegno di Studio, Oristano 1992: 139-51. Archivio Fotografico Sardo, Sassari.

Di Giovanni V, 1890: La topografia antica di Palermo dal secolo X al XV, Tip. e legatoria del Boccone del povero, Palermo.

Di Liberto M, 1993: Nuovissimo stradario storico della città di Palermo, Grifo, Palermo.

Di Stefano CA \& G Mannino 1984: Carta archeologica della Sicilia. Carta d'Italia. F. 249, Accademia di scienze lettere ed arti, Palermo.

Fazello T, 1628: Le due deche dell'Historia di Sicilia, dal Ciotti nella stamperia di Decio Cyrillo, Palermo.

Garofano I, 1997-1998: Palermo. Scoperte archeologiche nel monastero di Montevergine, Kokalos, 43, 44, 2 , 583-86.

Humphrey JH, 1986: Roman circuses. Arenas for chariot racing, B. T. Batsford, London.

Spatafora F \& G Montali 2006: Palermo: nuovi scavi nell'area di Piazza della Vittoria, in Osanna M \& Torelli M (ed.), Sicilia ellenistica, consuetudo italica: 140-51. Edizioni dell'Ateneo, Rome.

Storchi P, 2013: Per l'identificazione dell'anfiteatro di
Palermo romana e considerazioni su altri edifici per spettacolo, Atlante tematico di Topografia antica, 23, 62-71.

Tamburello I, 1971: Palermo punico-romana, Kokalos, 17, 81-96.

Todaro P, 1995: Palermo geologia del centro storico. Atlante geologico stratigrafico, D. Flaccovio, Palermo.

Uggeri G, 2004: La viabilità della Sicilia in età romana, M. Congedo, Galatina.

Vera D, 1996: Augusto, Plinio il Vecchio e la Sicilia in età imperiale, Kokalos, 42, 31-58.

Wilmott T, 2008: The Roman amphitheatre in Britain, The History Press, Stroud. 
